\title{
Methylal and Methylal-Diesel Blended Fuels for Use In Compression-Ignition Engines
}

\author{
Keith D. Vertin and James M. Ohi \\ National Renewable Energy Laboratory \\ David W. Naegeli and Kenneth H. Childress \\ Southwest Research Institute \\ Gary P. Hagen and Chris I. McCarthy \\ BP Amoco \\ Adelbert S. Cheng and Robert W. Dibble \\ University of California at Berkley
}

Reprinted From: State of Alternative Fuels Technologies, 1999

(SP-1458) 
SAE routinely stocks printed papers for a period of three years following date of publication. Direct your orders to SAE Customer Sales and Satisfaction Department.

Quantity reprint rates can be obtained from the Customer Sales and Satisfaction Department.

To request permission to reprint a technical paper or permission to use copyrighted SAE publications in other works, contact the SAE Publications Group.

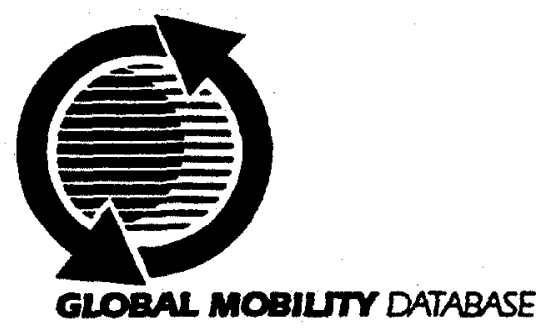

All SAE papers, standards, and selected books are abstracted and indexed in the Global Mobility Database.

\section{ISSN 0148-7191}

Positions and opinions advanced in this paper are those of the author(s) and not necessarily those of SAE. The author is solely responsible for the content of the paper. A process is available by which discussions will be printed with the paper if it is published in SAE Transactions. For permission to publish this paper in full or in part, contact the SAE Publications Group.

Persons wishing to submit papers to be considered for presentation or publication through SAE should send the manuscript or a 300 word abstract of a proposed manuscript to: Secretary, Engineering Meetings Board, SAE. 


\title{
Methylal and Methylal-Diesel Blended Fuels for Use In Compression-Ignition Engines
}

\author{
Keith D. Vertin and James M. Ohi \\ National Renewable Energy Laboratory \\ David W. Naegeli and Kenneth H. Childress \\ Southwest Research Institute \\ Gary P. Hagen and Chris I. McCarthy \\ BP Amoco \\ Adelbert S. Cheng and Robert W. Dibble \\ University of California at Berkley
}

\section{ABSTRACT}

"Gas-to-liquids" catalytic conversion technologies show promise for liberating stranded natural gas reserves and for achieving energy diversity worldwide. Some gas-toliquids products are used as transportation fuels and as blendstocks for upgrading crude-derived fuels.

Methylal $\left(\mathrm{CH}_{3}-\mathrm{O}-\mathrm{CH}_{2}-\mathrm{O}-\mathrm{CH}_{3}\right)$, also known as dimethoxymethane or DMM, is a gas-to-liquid chemical that has been evaluated for use as a diesel fuel component. Methylal contains $42 \%$ oxygen by weight and is soluble in diesel fuel.

- The physical and chemical properties of neat methylal and for blends of methylal in conventional diesel fuel are presented. Methylal was found to be more volatile than diesel fuel, and special precautions for distribution and fuel tank storage are discussed.

Steady state engine tests were also performed using an unmodified Cummins B5.9 turbocharged diesel engine to examine the effect of methylal blend concentration on performance and emissions. Substantial reductions of particulate matter emissions have been demonstrated or 10 to $30 \%$ blends of methylal in diesel fuel. This research indicates that methylal may be an effective blendstock for diesel fuel provided design changes are made to vehicle fuel handling systems.

\section{INTRODUCTION}

Natural gas is considered to be a very desirable fuel by policy makers and environmentalists alike. Natural gas currently accounts for about $21 \%$ of energy use worldwide, and about $24 \%$ of total energy consumption in the United States [1]. Global natural gas consumption is about 78 TCF (trillion cubic feet) annually, and is forecasted to increase to 133 TCF by 2010 as the woridwide energy demand increases.

By some estimates, 2000 to 7000 TCF of natural gas is beyond the reach of economic markets in its gaseous state or as liquefied natural gas $[2,3]$. There has recently been a proliferation of "gas-to-liquids" (GTL) projects worldwide [4], in many cases to make use of remote natural gas reserves, to monetize associated gas, and to avoid gas flaring or re-injection. Some countries have promoted GTL projects to monetize their domestic energy resources, and have developed strategies to produce value-added GTL chemicals and synthetic fuels for niche markets. GTL may enable the conversion of natural gas to chemicals and liquids that can be transported to market more cost-effectively than by natural gas pipelines or by LNG tankers. The production economics of GTL fuels and chemicals become favorable as worldwide oil prices exceed about $\$ 18$ per barrel $[4,5]$. 
GTL products are currently being used as transportation fuels in select markets. Fischer-Tropsch synthetic diesel is used as a neat transportation fuel in parts of South Africa today. Fischer-Tropsch diesel has also been used as a blendstock for upgrading crude-derived fuels to meet California on-highway diesel fuel standards. GTL products can be sold at a premium price over crude oil products because of their favorable environmental characteristics.

Consideration of other GTL chemicals for use as oxygenates or as future transportation fuels is warranted, because they may offer properties conducive to low vehicle emissions. Methanol $\left(\mathrm{CH}_{3}-\mathrm{OH}\right)$ is used as an alternative fuel for spark-ignition engines. However, methanol blends are less suited for use in diesel engines because methanol is insoluble in diesel fuel and a surfactant is required to produce stable fuel mixtures. Methanol is slow to autoignite (cetane number of zero), and methanol emulsions can significantly diminish the cetane number of diesel fuel $[6,7,8]$. Engine tests have been performed to study the potential for methanol blending strategies to extend diesel fuel supplies $[6,7]$. Substantial engine design changes are required to autoignite neat methanol or M85 in diesel engines, including higher compression ratio pistons and glow plugs.

Dimethyl ether (or DME, $\mathrm{CH}_{3}-\mathrm{O}-\mathrm{CH}_{3}$ ) has shown promise in the research laboratory because it has excellent autoignition characteristics and burns nearly soot-free in compression ignition engines $[9,10]$. However, DME is also not readily used in unmodified diesel engines due to its high volatility, low viscosity and poor lubricity. Research is underway to develop highly engineered fuel delivery and direct injection systems for DME [11,12].

Glycol ethers such as monoglyme and diglyme have been used to oxygenate diesel fuel in controlled engine tests $[13,14]$. Although effective at reducing ignition delay and particulate matter emissions in diesel engines, safety concerns arise from these substances because of their teratogenic quality and the possible consequences in the event of ground water contamination. These concerns arise in part from toxic potency testing by oral dosage in mice [15-17]. Further research is warranted to study the impacts of ethylene glycol ethers on health and the environment.

Methylal $\left(\mathrm{CH}_{3}-\mathrm{O}-\mathrm{CH}_{2}-\mathrm{O}-\mathrm{CH}_{3}\right)$ also known as dimethoxymethane or DMM, is another gas-to-liquid chemical that has been evaluated for use as a diesel fuel component. Methylal is a colorless liquid and is $100 \%$ miscible in diesel fuel. Methylal contains $42 \%$ oxygen by weight, has no carbon-carbon atomic bonds, and has a relatively high hydrogen-to-carbon ratio, and all of these characteristics correlate with very low soot formation during diffusion flame combustion $[18,19]$. Methylal has about $55 \%$ of the energy density of diesel fuel, but blending $20 \%$ by volume in conventional diesel fuel only lowers the energy density of the blended fuel by about $10 \%$.

Methylal is currently a specialty chemical produced in small batches and in very pure grades. It is used as a solvent in household and industrial sprays, as a blowing agent for polyurethane foams, and in the production of ion exchange resins [20]. High purity methylal is used in cosmetics and pharmaceuticals, and therefore has a well documented, irreproachable toxicological profile that has been summarized by other researchers [21]. Methylal is also biodegradable, and has a good ecotoxicological profile [22].

The atmospheric lifetime of methylal was estimated to be 2-4 days based on smog chamber studies [23], which is considerably longer than some gasoline constituents that photochemically react within hours. Due to this relatively slow reactivity, methylal can be removed from the urban environment by rainout or by the jet stream before photochemical reactions occur, suggesting that fugitive and uncombusted methylal emissions will not significantly contribute to ozone in urban areas.

In small production volumes, methylal is synthesized in near quantitative yield via the catalyzed reaction of methanol with formaldehyde:

$$
2 \mathrm{CH}_{3} \mathrm{OH}+\mathrm{CH}_{2} \mathrm{O} \rightarrow \mathrm{CH}_{3} \mathrm{OCH}_{2} \mathrm{OCH}_{3}+\mathrm{H}_{2} \mathrm{O}
$$

For larger scale production, methanol would be synthesized from natural gas at the plant, and formaldehyde for this reaction would be obtained by oxidative dehydrogenation of methanol. Methylal may also be produced via the oxidation of DME, or through the co-production and reaction of DME and methanol via a two-step process. The cost of producing methylal is dependent on the production economics of methanol, formaldehyde, and/or DME. Production costs, product value and pricing are closely guarded trade secrets and therefore not reported here.

Methylal is currently produced by Synthite Ltd. (UK) with a capacity of about $5000 \mathrm{MT} /$ year and Lambiotte \& CIE (Belgium) with a capacity of 10000-12000 MT/year. From patent information, the Lambiotte process incorporates a catalytic distillation reactor to obtain an almost quantitative yield of azeotropic methylal $(93 \%$ methylal, $7 \%$ methanol). After neutralization with base, the azeotropic product is fed to an extractive distillation tower utilizing water as the extraction medium. After drying of the overhead product, very high purity methylal $(>99.9 \%)$ is obtained.

REVIEW OF PREVIOUS RESEARCH- The researchers have previously examined the physical and chemical properties and chemical kinetics of methylal to determine its suitability for use in compression-ignition engines [ 24 25]. This earlier research revealed that methylal was miscible in diesel fuel in all proportions, had a boiling point of $42^{\circ} \mathrm{C}$ and autoignition temperature of $237^{\circ} \mathrm{C}$. Pyrolysis experiments were also carried out using a 


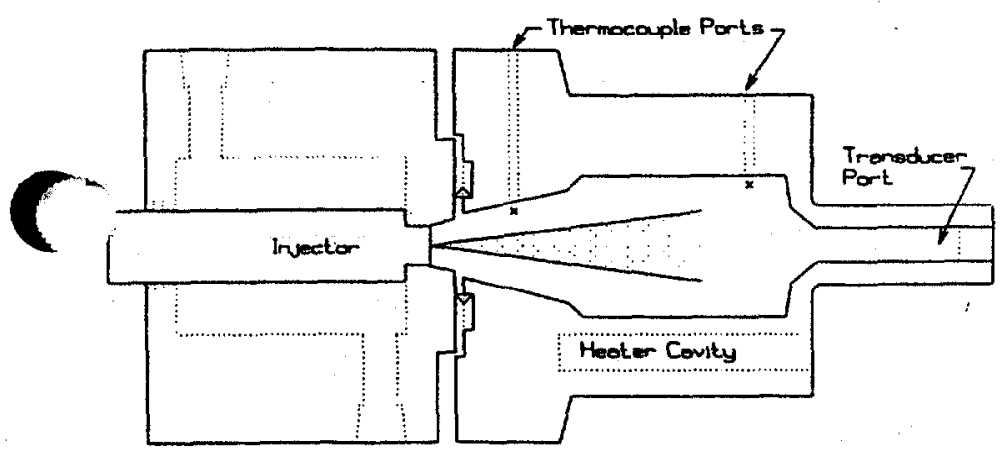

Figure 1. Constant Volume Combustion Bomb Apparatus (CVCA) Used for Ignition Delay Measurements

constant volume combustion bomb apparatus (Figure 1). The apparatus was used to measure the ignition delay of methylal sprays for comparison to diesel reference fuels, and a correlation was used to estimate the cetane number (Figure 2, and [25-28]). Similar experimental correlations have been performed over several years, and the estimated cetane number of $99+\%$ purity methylal has ranged from 29 to 57 . This variation may be partly due to the volatile nature of methylal compared to diesel fuel, non-standard test equipment, and the sensitivity of the cetane correlation to slight differences in ignition delay measurements.

Methylal-diesel blends have been tested in a variety of unmodified diesel engines. Perhaps the earliest tests were performed in a Caterpillar 3306B DITA 10.5 litre diesel engine equipped with a pump-line-nozzle fuel injection system [24,25]. A $20 \%$ blend of methylal in diesel fuel was shown to reduce smoke opacity by about $50 \%$ at start-up and high idle (Figure 3). Moreover, the engine produced virtually no smoke when fueled with neat $(100 \%)$ methylal, and did not misfire at these operating conditions.

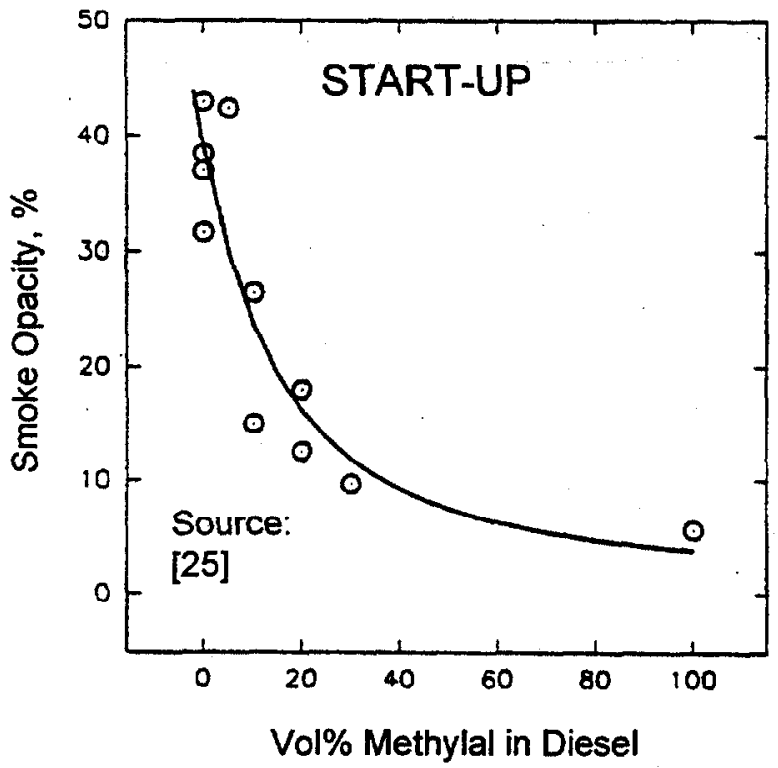

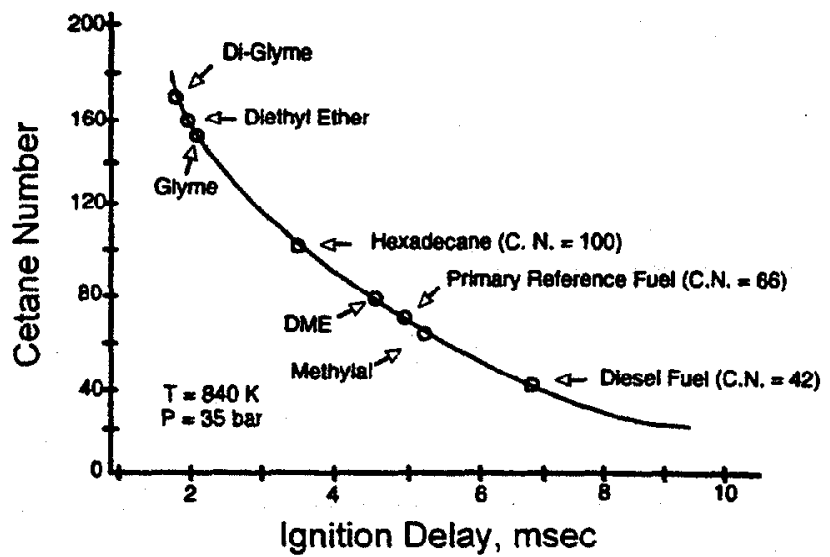

Figure 2. Typical Correlation Curve for Estimating Cetane Number [28]

More recently, a $15 \%$ methylal blended fuel was tested in a Daimler-Benz OM611 2.2 litre turbodiesel at 13 steady state operating modes [29]. The engine was equipped with a common rail fuel system and was calibrated for European passenger car applications. A fuel consisting of $15 \%$ methylal blended in ultra-low sulfur diesel emitted $52 \%$ lower particulate matter (PM) and $4 \%$ lower oxides of nitrogen (NOx) compared to a conventional diesel fuel, based on modal-averaged engine-out emissions measurements. This $15 \%$ methylal blend emitted 39\% lower PM compared to the ultra-low sulfur base fuel itself. No significant differences in engine-out particle size distributions were apparent for the fuels tested.

Testing of $10 \%$ and $20 \%$ blends of methylal in a diesel reference fuel has been performed on a Peugot PSA XUD9A 1.9 litre indirect injection engine equipped with an oxidation catalyst [20]. At $2000 \mathrm{rev} / \mathrm{min}$ high-load

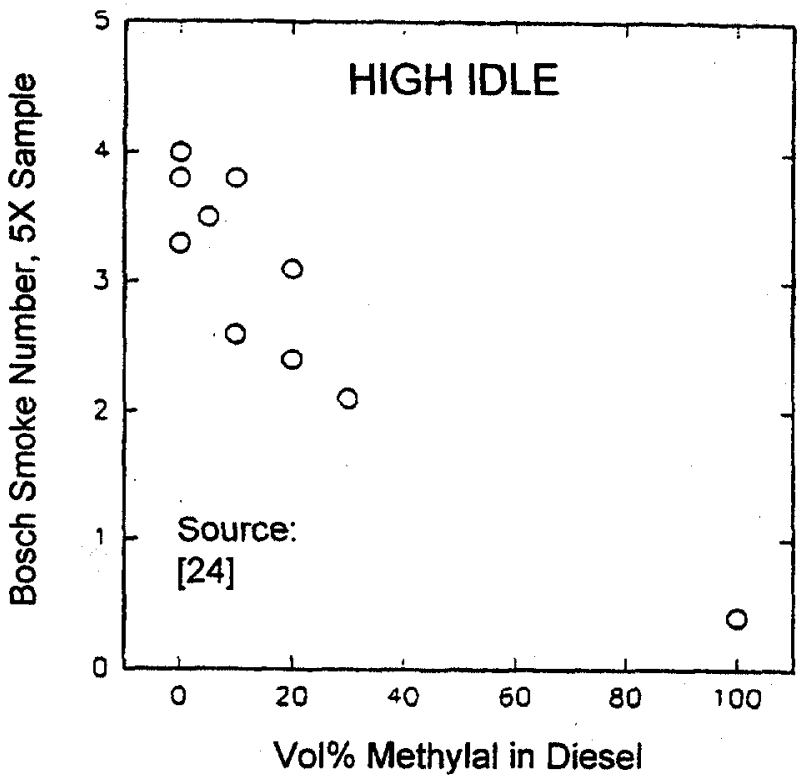

Figure 3. Smoke Reductions for Methylal Blends Tested in an Unmodified Diesel Engine [24,25] 
conditions, the methylal blended fuels emitted less than half of the PM compared to the diesel reference fuel, before and after the catalyst. Substantial PM reductions were also evident over the load range of the engine.

Ford Motor Company has recently performed advanced particle measurements for $16.6 \%$ and $30 \%$ methylal blends in diesel fuel. A 1995 European passenger car equipped with a 1.8 litre indirect injection turbodiesel and oxidation catalyst was tested on a chassis roll dynamometer [30]. The researchers found that blending methylal in diesel fuel caused the particle size distribution to shift to smaller diameters. Ultrafine particle emissions were more predominant under higher road load conditions.

In summary, prior research has demonstrated that methylal can be an effective oxygenate for diesel fuel, and significant particulate matter reductions have been demonstrated using a variety of diesel engines.

THE PURPOSE OF THIS RESEARCH- Further laboratory research has been carried out to better assess the suitability of methylal for use as a transportation fuel. This new research has studied the effect of blend concentration on fuel properties and engine emissions, and has focused on collecting data that is lacking or unavailable in the public domain, including:

- Measurement of fundamental physical and chemical properties for neat methylal and for 10 , 20,30 and $40 \%$ methylal blended in a diesel reference fuel.

- Development of a vehicle fuel tank and delivery system concept design, to enable safe handling of methylal-diesel blended fuels on-board vehicles.

- Steady state engine testing to quantify the effect of methylal blend level on engine-out emissions.

\section{RESULTS}

\section{PHYSICOCHEMICAL PROPERTIES}

Laboratory experiments were performed to more completely characterize the physical and chemical properties of methylal, and to study the effect of blend concentration on fuel properties. Seven test fuels have been evaluated (all blends are on a volumetric basis):

- DF2, Phillips No. 2 Diesel Reference Fuel (10\% aromatics)

- $10 \%$ methylal blended in DF2

- $20 \%$ methylal blended in DF2

- $30 \%$ methylal blended in DF2

- $40 \%$ methylal blended in DF2

- Pure methylal (99.6\% purity)

- Impure methylal

(92\% DMM, $7.5 \%$ methanol, $0.5 \%$ water)
Test results for these seven fuels are reported in Table 1. The properties that are of most importance to engine and vehicle designers are discussed in more detail below.

CETANE NUMBER- The cetane number of neat methylal has ranged from 29 to 57 in various reports, but these estimates were based on ignition delay measurement correlations as discussed previously. To definitively quantify the cetane number of methylal, ASTM D 613 tests were performed using the standard single-cylinder CFR engine (Figure 4). Cetane numbers were also measured using a modified D 613 test procedure that accounted for the large difference in the heats of combustion of the test fuels.

The standard D 613 procedure calls for a fixed fuel supply rate of $13 \mathrm{cc} /$ minute irrespective of the fuel's stoichiometric fuel-air ratio. The methylal-containing fuels have lower heats of combustion, so the enthalpy per unit volume of fuel injected and the overall equivalence ratio were lower for these fuels. As a result, the engine runs cooler and the in-cylinder compression temperature is lowered. Since autoignition of the fuel is strongly dependent on temperature and the leaner mixtures are harder to ignite, this suggests that the ignition delay times for fuels containing methylal are extended as a consequence of the test procedure.

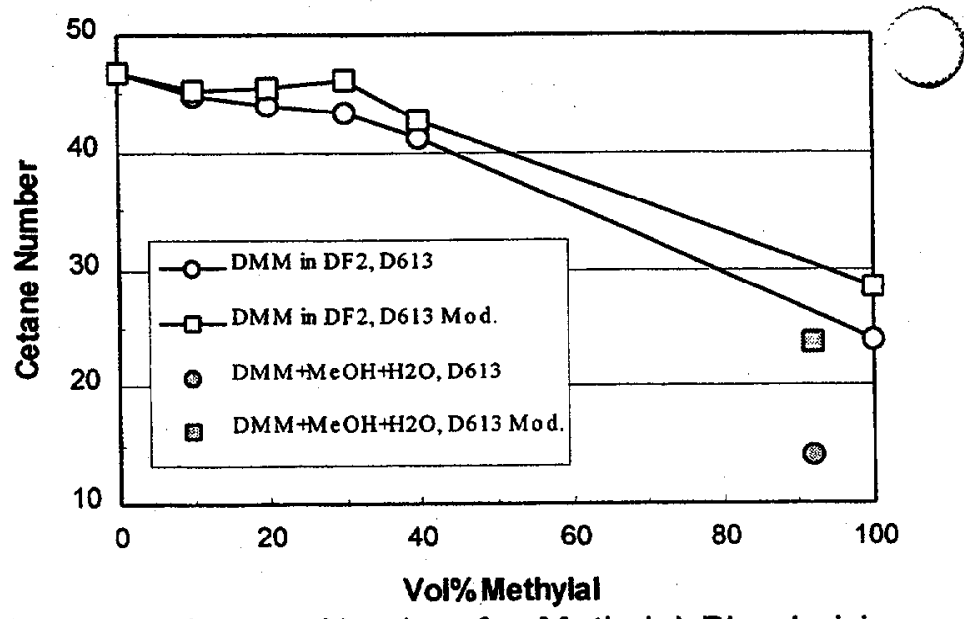

Figure 4. Cetane Number for Methylal Blended in Diesel Fuel

A modified D 613 test procedure was used to more fairly compare the autoignition quality of the test fuels. For the modified test procedure, the fuel flow rates of the test fuels were adjusted to maintain an energy input equivalent to that of the baseline diesel fuel.

From these test results, it is apparent that neat methylal has a cetane number of 29 by the modified method. Clearly, methylal will not improve the cetane number of conventional diesel fuels. But methylal may still be an effective blending agent, because it does not reduce the cetane number of diesel fuel until concentrations exceed about $30 \%$ by volume. The cetane number of methylal 
Table 1. Test Fuel Properties

\begin{tabular}{|c|c|c|c|c|c|c|c|}
\hline Test Fuel No.: & 1 & 2 & 3 & 4 & 5 & 6 & 7 \\
\hline Test Fuel Name & DF2 & DMM10 & DMM20 & DMM30 & DMM40 & $\overline{\mathrm{DMM}}$ & $\overline{\mathrm{DMMX}}$ \\
\hline Identification No. & AL25607F & AL25623F & AL25624F & AL25625F & AL25626F & AL25614F & AL25676F \\
\hline Base Fuel Diesel No.2, vol.\% & 100 & 90 & 80 & 70 & 60 & 0 & 0 \\
\hline Methylal, vol.\% & $\overline{0}$ & 10 & 20 & 30 & 40 & 100 & 92 \\
\hline Methanol, vol.\% & 0 & 0 & 0 & 0 & 0 & 0 & 7.5 \\
\hline Water, vol.\% & 0 & 0 & 0 & 0 & 0 & 0 & 0.5 \\
\hline Water, ppm by Wt. & 161 & 210 & 229 & 311 & 340 & 773 & 5950 \\
\hline Carbon, Wt.\% & 85.77 & 82.85 & 80.23 & 76.53 & 72.63 & 47.37 & 46.46 \\
\hline Hydrogen, Wt.\% & 13.83 & 13.56 & 13.2 & 13.11 & 12.62 & $\overline{10.13}$ & 10.58 \\
\hline Sulfur, Wt.\% & 0.033 & 0.03 & 0.026 & 0.023 & 0.019 & 0 & $\overline{0}$ \\
\hline Oxygen by Diff., Wt. $\%$ & 0.37 & 3.56 & 6.54 & 10.34 & 14.73 & 42.5 & 42.96 \\
\hline Density, kg/litre @ $15^{\circ} \mathrm{C}$ & 0.8309 & 0.8324 & 0.8364 & 0.8372 & 0.8401 & 0.8668 & 0.8649 \\
\hline Cloud Point by D $2500,{ }^{\circ} \mathrm{C}$ & -23 & -27 & -29 & -31 & -32 & $<-52$ & $<-52$ \\
\hline Gross Heat of Comb. by D $240, \mathrm{MJ} / \mathrm{kg}$ & 46.14 & 43.18 & 41.81 & 39.52 & 37.82 & 25.49 & 22.89 \\
\hline Net Heat of Comb. by D 240, MJ/kg & 43.08 & 40.30 & 39.01 & 36.74 & 35.14 & 23.26 & 20.64 \\
\hline Heat of Vaporization, $\mathrm{J} / \mathrm{mole}$ & 28101 & 28466 & 29167 & 30290 & 30085 & 30610 & 28783 \\
\hline Viscosity by D445@ 40º,cSt & 2.42 & 2.00 & 1.26 & 0.98 & 0.79 & 0.33 & 0.34 \\
\hline Saturates by FIA, D 1319, vol.\% & 89.6 & $-\cdots$ & $\ldots$ & $-\cdots$ & $\ldots$ & 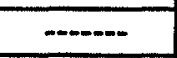 & $\cdots$ \\
\hline Olefins by FIA, D 1319, vol.\% & 2.2 & $-\cdots$ & $\cdots$ & $-\cdots$ & $-\cdots-\cdots$ & $\ldots$ & - \\
\hline Aromatics by FIA, D 1319, vol.\% & 8.2 & $\ldots$ & ----- & 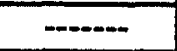 & 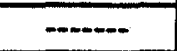 & $\overline{n-\cdots}$ & - $\cdots$ \\
\hline Ash by D $482, \mathrm{Wt} . \%$ & 0.001 & $-\cdots$ & $\cdots$ & $-\cdots$ & $\ldots$ & $\ldots$ & -...- \\
\hline $\begin{array}{l}\text { Ramsbottom Carbon Residue on } 10 \% \\
\text { Distillation residue by D 524, Wt.\% }\end{array}$ & 0.06 & 0.07 & 0.08 & 0.07 & 0.08 & -.--- & ---.-- \\
\hline Copper Strip Corrosion by D 130 & $1 \mathrm{~A}$ & $\mathrm{IA}$ & $1 \mathrm{~A}$ & $\overline{1 \mathrm{~A}}$ & $\overline{1 A}$ & $\overline{1 \mathrm{~A}}$ & $1 \mathrm{~A}$ \\
\hline Reid Vapor Pressure, mbar & 6.2 & 277.9 & 466.1 & 590.2 & 670.2 & 863.9 & 894.9 \\
\hline Flash-Point by D $56,{ }^{\circ} \mathrm{C}$ & 67 & $-14^{*}$ & $-21^{*}$ & $-25^{*}$ & $-25^{*}$ & $-28^{*}$ & $-27^{*}$ \\
\hline Lower TLF, ${ }^{\circ} \mathrm{C}$ & 63 & -19 & -26 & -29 & -29 & -32 & -31 \\
\hline Upper TLF, ${ }^{\circ} \mathrm{C}$ & 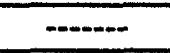 & 20 & 6 & 3 & 1 & -4 & -3 \\
\hline Autoignition Temperature, ${ }^{\circ} \mathrm{C}$ & 233 & 232 & 233 & 231 & 231 & 228 & 237 \\
\hline Cetane Number by D 613 & 46.7 & 44.8 & 44.1 & 43.3 & 41.3 & 24.0 & 14.1 \\
\hline Cetane Number, Modified D613 & 46.7 & 45.4 & 45.5 & 46.2 & 42.8 & 28.5 & 23.7 \\
\hline Cetane Index & 50.2 & 49.1 & 46.9 & 45.0 & 39.7 & 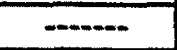 & -an \\
\hline Ignition Delay at $515^{\circ} \mathrm{C}, \mathrm{msec}$ & 7.50 & 6.93 & 7.11 & 7.40 & 7.83 & 8.35 & 12.07 \\
\hline Ignition Delay at $570^{\circ} \mathrm{C}, \mathrm{msec}$ & 3.22 & 3.30 & 3.57 & 3.43 & 3.72 & 4.33 & 7.85 \\
\hline Cetane Number by CVCA@ $915^{\circ} \mathrm{C}$ & 41.3 & 47.4 & 45.4 & 42.3 & 38.2 & 34.1 & 17.5 \\
\hline Cetane Number by CVCA @ 570 ${ }^{\circ} \mathrm{C}$ & 46.2 & 44.4 & 39.1 & 41.7 & 36.7 & 29.3 & 14.6 \\
\hline Lubricity by HFRR D6079 Mod., microns & 685 & 700 & 755 & 760 & 765 & 700 & 790 \\
\hline Initial Peroxides by $\mathrm{D} 3703, \mathrm{ppm}$ & $<5$ & $<5$ & $<5$ & $<5$ & $<5$ & $<5$ & $<5$ \\
\hline Initial Gum by D $381, \mathrm{mg} /$ dlitre & 40.4 & 33.0 & 31.9 & 20.7 & 18.7 & 0 & 0 \\
\hline Smoke Point by D1322, mm & 26.0 & 26.7 & 30.3 & 32.7 & 34.0 & None & None \\
\hline \multicolumn{8}{|l|}{ Distillation by $\mathrm{D} 86,{ }^{\circ} \mathrm{C}$} \\
\hline Initial Boiling Point & 199 & 43 & 42 & 42 & 42 & 42 & 41 \\
\hline $10 \%$ & 218 & 210 & 50 & 44 & 42 & --..--- & 42 \\
\hline $50 \%$ & 252 & 250 & 247 & 241 & 227 & --.-- & 42 \\
\hline $90 \%$ & 289 & 303 & 288 & 289 & 282 & -..-- & 43 \\
\hline End Point & 358 & 357 & 352 & 349 & 339 & -...... & 86 \\
\hline
\end{tabular}

* Calculated assuming the Flash Point is about $4^{\circ} \mathrm{C}$ above the Lower TLF. 
was significantly lowered by the addition of $7.5 \%$ methanol and $0.5 \%$ water.

The lower cetane number of neat methylal does not necessarily exclude it from consideration as a future fuel for next-generation compression-ignition engines. The ASTM D613 standard cautions "This test may be used for unconventional fuels such as synthetics... However, the relationship to the performance in full scale engines is not completely understood". This statement arises partly because the CFR test engine has a prechamber with a horizontally-oriented injector, and natural aspiration, making it not very representative of a modern on-highway turbocharged diesel engine. The low cetane number of methylal is also in apparent contradiction with other findings: neat methylal has been run at high idle without misfires [24], and has a favorable autoignition temperature of $228^{\circ} \mathrm{C}$. Moreover, future engine designs may differ substantially by today's standards and thus may be more tolerant of synthetic fuels that have longer ignition delays.

KINEMATIC VISCOSITY- Methylal has a strong influence on the viscosity of diesel fuel (Figure 5). Low viscosity fuels may not perform well in unmodified diesel fuel injection systems due to seal leakage, fuel leakage past the pumping elements and control solenoids, and excessive fuel spill back to the fuel tank. These problems have been encountered by researchers attempting to fuel engines with DME [9-12]. Methylal is expected to be less problematic than DME, since it has a higher viscosity and has been successfully run in unmodified engines.

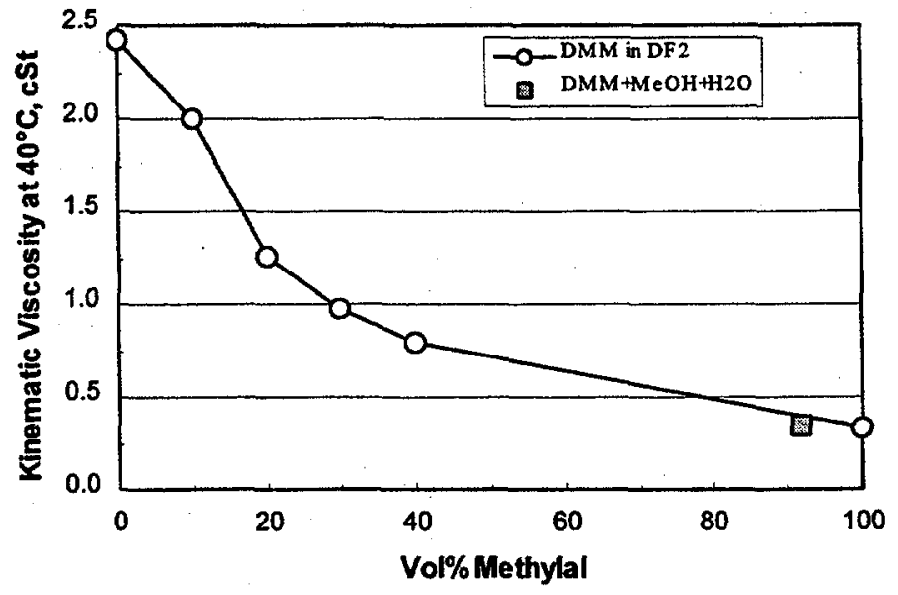

Figure 5. Kinematic Viscosity of Methylal Blended in Diesel Fuel

FUEL LUBRICITY - A unique, pressurized high frequency reciprocating rig has been developed to allow lubricity testing of volatile fuels such as methylal and DME (Figure 6, [31]). The rig features a sealed chamber that prevents the fuel sample from evaporating during the test. The test results reveal that the lubricity of methylal is similar to a $10 \%$ aromatics reference fuel (Figure 7). Methylal is not expected to cause the short-hour wear failures that have been encountered when testing engines fueled with DME. The lubricity of methylal was diminished by the addition of $7.5 \%$ methanol and $0.5 \%$ water.

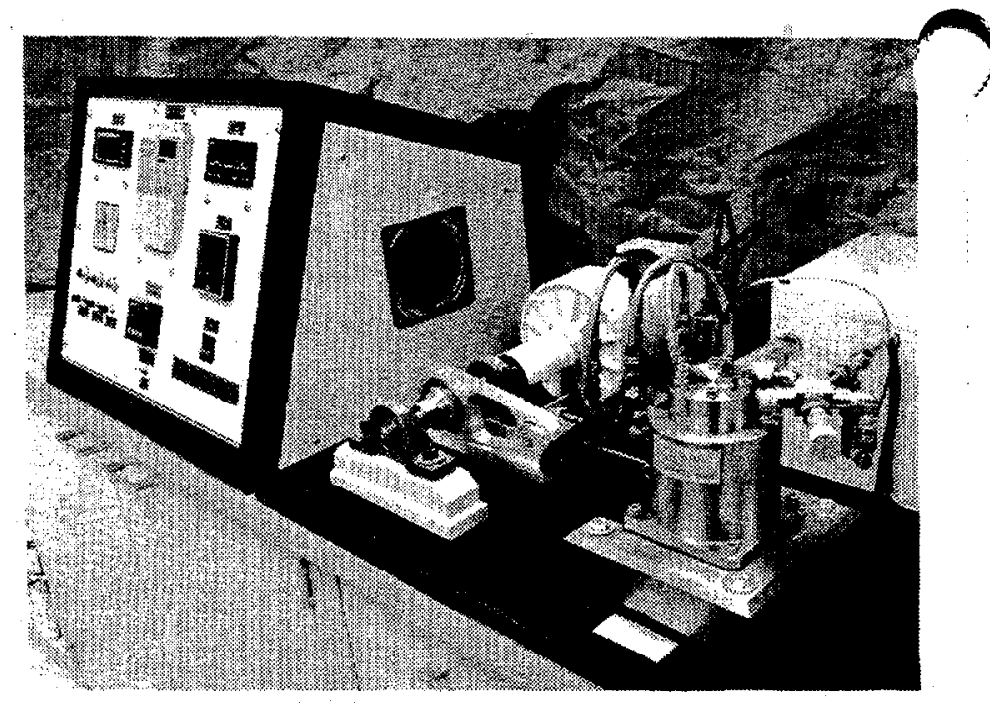

Figure 6. Pressurized High Frequency Reciprocating Rig for Fuel Lubricity Testing

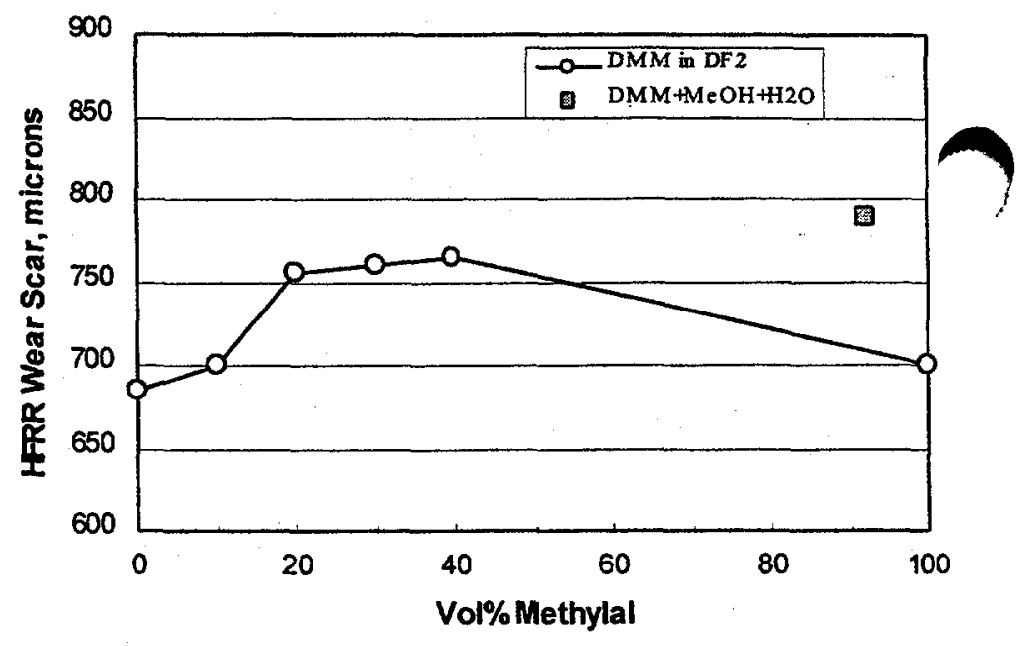

Figure 7. Wear Scar Measurements from ASTM D6079 (Mod.) Fuel Lubricity Tests

VAPOR PRESSURE- Methylal is more volatile than diesel fuel, with a boiling point of $42^{\circ} \mathrm{C}$ and a Reid Vapor Pressure (RVP) of 0.86 bar. When methylal is added to diesel fuel, the RVP becomes similar to that of gasoline. The RVP and vapor pressure of the test fuels at $71^{\circ} \mathrm{C}$ are shown in Figure 8.

In diesel powered vehicles, some fuel is used to cool engine components and then recirculated back to the fuel tank. Fuel temperatures as high as $71^{\circ} \mathrm{C}$ have been observed especially when the tank is nearly empty. The upper curve in Figure 8 shows that relatively high vapol pressures will develop in tanks containing methylal and methylal-diesel fuels at $71^{\circ} \mathrm{C}$. A conventional fuel tank would not be appropriate for methylal fuels at this 
temperature, because opening such a pressurized tank would result in excessive fugitive emissions and would be a flammability hazard. Rather, these results suggest that a sealed fuel tank is needed to contain the fuel vapors, and a quick-disconnect type dispensing nozzle (equipped with a vapor recovery system) would be needed to fill the tank thereby preventing the sudden release of fugitive emissions.

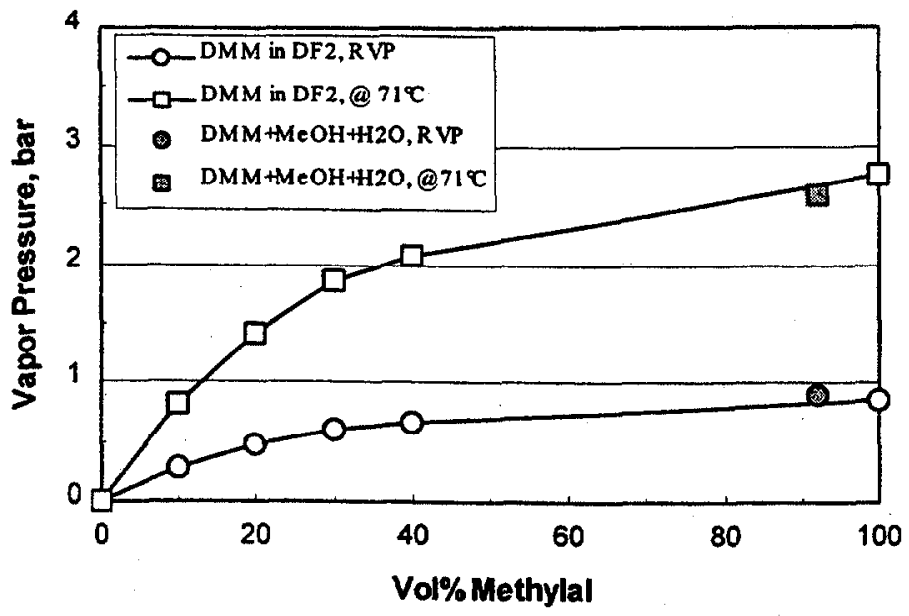

Figure 8. Vapor Pressure of Methylal Blended in Diesel Fuel

FLAMMABILITY - The upper and lower temperature limits of flammability (TLF) were measured for the test fuels to assess the fuel tank flammability hazard (Figure 9). The upper TLF is the temperature at which the upper explosion limit exists in dry air under conditions of vaporliquid equilibrium. For tank temperatures above the upper TLF, fuel tank vapors are too rich to propagate a flame away from an ignition source. For tank temperatures below the lower TLF, vapors are too lean to propagate a flame. Fuel tank vapors are flammable in the region bound by the upper and lower TLF curves.

The upper TLF is $6^{\circ} \mathrm{C}$ for $20 \%$ methylal blended in diesel, indicating that fuel tank vapors would be ignitable in colder climates if exposed to an ignition source. Neat methylal vapors would be ignitable between $-4^{\circ} \mathrm{C}$ to $-32^{\circ} \mathrm{C}$. A vapor pressure enhancing additive such as DME or diethyl ether could be used to further reduce the upper TLF to allow safe storage of methylal-containing fuels in colder climates.
PEROXIDES \& GUMS- The storage stability of the test fuels was evaluated by aging samples in fuel cans over a five month period at $40^{\circ} \mathrm{C}$. The vapor space in each can was purged with pure oxygen before being sealed. Samples were taken monthly and tested for peroxides and gum content. Peroxides can lead to chemical instability over time, and may cause deterioration of elastomer seals. No peroxides were detected in the fuel samples after five months. Gums are polymeric substances that may lead to harmful deposits and injector fouling. The base diesel fuel contained a significant amount of gum, but gum content remained constant for all samples over the five month aging period.

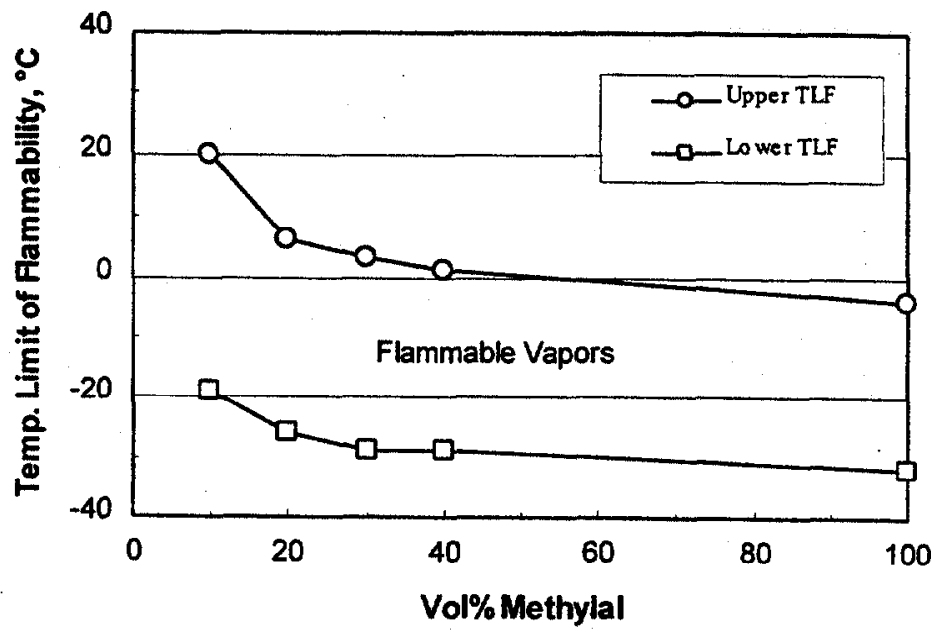

Figure 9. Temperature Limits of Flammability (TLF) for Methylal Blended in Diesel Fuel

ELASTOMER COMPATIBILITY- Five o-ring materials were immersed in diesel fuel, neat methylal, and a $20 \%$ methylal- $80 \%$ diesel fuel blend for $\mathbf{4 2}$ hours to determine if the methylal is compatible with elastomeric seals used in typical fuel injection systems. The affect of neat diesel fuel on the o-rings was negligible. Some swelling and elongation was apparent for o-rings immersed in the methylal-diesel blend, and was especially prevalent for o-rings exposed to neat methylal (Table 2). Fluorocarbon elastomers were more adversely affected than the nitrile materials.

Table 2. Effects of Neat DMM and 20\% DMM in DF2 on O-ring Seal Swelling

\begin{tabular}{|l|c|c|c|c|}
\hline \multirow{2}{*}{$\begin{array}{c}\text { Type of Elastomer in } \\
\text { O-ring Seal }\end{array}$} & \multicolumn{2}{|c|}{ Thickness - \% Change } & \multicolumn{2}{c|}{ Elongation - \% Change } \\
\cline { 2 - 5 } & Neat DMM & $20 \%$ DMM & Neat DMM & $20 \%$ DMM \\
\hline $\begin{array}{l}\text { Fluorocarbon Non-Black } \\
\text { Filled }\end{array}$ & 14.9 & 6.9 & 26.7 & 5.5 \\
\hline Fluorocarbon Black Filled & 20.8 & 7.9 & 22.8 & 8.9 \\
\hline General Purpose Nitrile & 10.7 & 4.0 & 10.4 & 3.9 \\
\hline High ACN Nitrile & 6.8 & 2.3 & 6.3 & 1.7 \\
\hline Peroxide Cured E.R. Nitrile & 5.7 & 2.3 & 11.2 & 7.5 \\
\hline
\end{tabular}




\section{FUEL DISTRIBUTION AND DESIGN ISSUES}

Methylal-diesel blends are more volatile than conventional diesel fuels, and could not safely be substituted for diesel fuel in unmodified vehicles. Changes in fuel distribution techniques, refueling stations, and vehicle designs would be required if methylal-diesel blended fuels were to be used in the United States.

FUEL DISTRIBUTION AND REFUELING - it is envisioned that methylal would be blended with diesel fuel at the rack, much like ethanol is blended into gasoline today. Special refueling stations may be required to fill the vehicle fuel tank and recover displaced fuel tank vapors. A unique quick-disconnect dispensing nozzle may be needed for refueling to prevent the release of pressurized fuel vapors.

FUEL TANK DESIGN- Significant changes to the diesel fuel tank would be required to safely handle methylalcontaining fuels on-board the vehicle. A sealed fuel tank is required to contain the fuel vapors, and a quickdisconnect type nozzle could be used to fill the tank thereby preventing the sudden release of fugitive emissions. Precautions must also be taken to reduce the risk of fuel tank explosions in colder climates.

A methyial fuel tank design could simply resemble a gasoline fuel tank system, but must be capable of containing fuel vapor pressures up to 4 bar (60 psi). The sealed fuel tank would require evaporative emission control features similar to those in passenger cars. In colder climates, the fuel tank vapors may at times be ignitable in the presence of an ignition source. This potential safety hazard could be addressed by adding a higher volatility fuel component such as DME to all methylal-containing fuels formulated for colder climates, to ensure the fuel vapors were too rich to burn.

Alternatively, a new fuel tank design has been conceived for fuels containing methylal (Figure 10). This concept eliminates the vapor space in the tank and therefore could be safely used for vehicles operating in all climates.

The fuel tank has a bladder and is filled with pressurized fuel using a non-spill quick-disconnect type nozzle. While the method of filling is to prevent vapors from escaping and air from entering, a mechanism is included to vent the tank because there is still a possibility that air might accumulate over time. Air is vented through the coiled tube leading from the top of the bladder to the solenoid valve at the top of the figure. A computer controller only allows the solenoid valve to open when the engine is started and when the fuel temperature is below a safe level. When the solenoid valve opens, the gases inside the bladder are drawn out into the intake manifold of the engine. A protocol would have to be developed to specify the frequency and duration with which the solenoid valve would be opened.
The fuel transfer pump is placed outside the tank where it is cooler than the fuel inside. The fuel delivery pressure would exceed the vapor pressure at the inlet to the injection pump. Assuming the injection pump operates at about $71^{\circ} \mathrm{C}$, the fuel delivery pressure would need to be greater than 1.4 bar to prevent cavitation of a $20 \%$ methylal- $80 \%$ diesel blend. The fuel transfer pumps used in fuel injected gasoline vehicles would seem to provide adequate delivery pressure for light duty applications.

\section{Sealed Air-Free Fuel Tank}

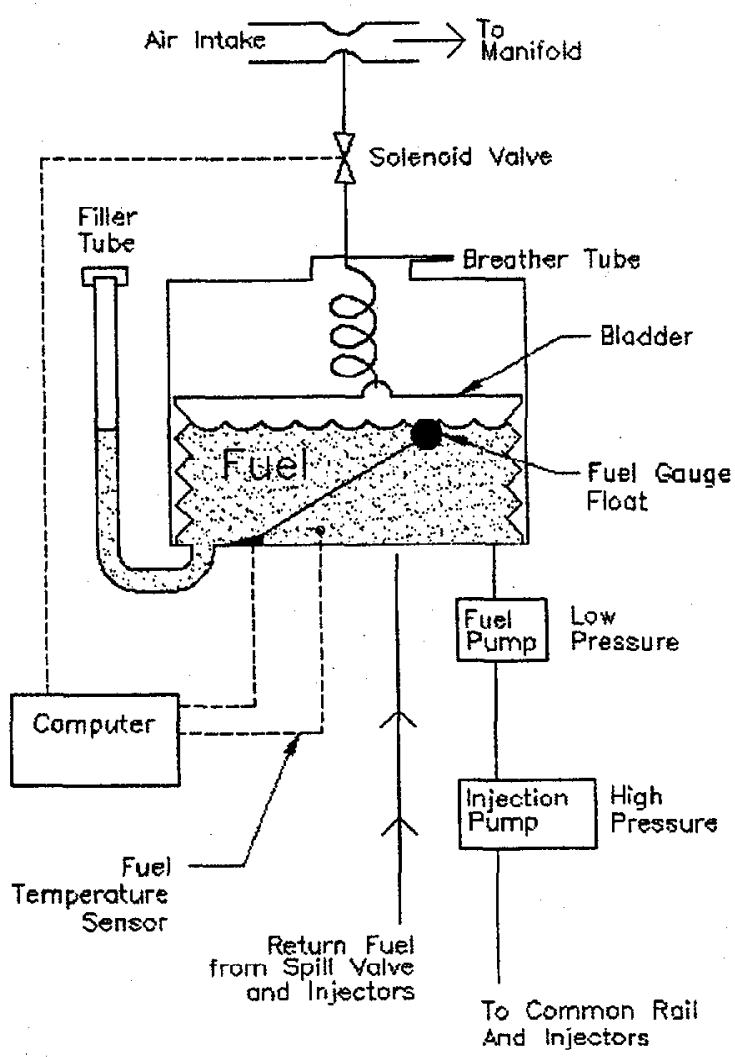

Figure 10. Fuel Tank Concept for MethylalContaining Fuels

ENGINE DESIGN- Several research laboratories have successfully run unmodified diesel engines on diesel fuels containing up to $30 \%$ methylal. This experience suggests that there is no requirement to invent novel fuel injection systems or combustion systems to utilize methylal-diesel blended fuels in compression-ignition engines. However, the engine designer may need to consider the following issues in order to optimize engine performance for use with methylal-diesel fuels: 
- Due to the lower energy density of methylal-diesel blends, larger fuel injection volumes are required to develop rated power from the engine.

- The lower viscosity of the blended fuel causes increased fuel recirculation (spill) in unmodified engines.

- Methylal may not be compatible with some types of seals used in fuel injection equipment. More elastomer compatibility studies are in progress.

- Methylal-diesel blends are more volatile than conventional diesel fuel, and potential safety hazards should be identified especially if the fuel is also used as a coolant.

- Substantial emissions benefits can be realized, especially if fuel injection strategies were optimized for fuels containing methylal.

\section{ENGINE TESTING}

Engine laboratory tests were performed to examine the effect of methylal blend concentrations on engine-out regulated exhaust emissions. Pure methylal was blended in $5,10,20$, and $30 \%$ concentrations by volume in a baseline diesel fuel and stored in airtight fuel tanks. The baseline diesel fuel "D2" was also tested for comparison with the blended fuels, and properties are listed in Table $3 . \quad$ Tests were performed on an unmodified 1993 Cummins B Series 5.9 litre turbocharged and aftercooled diesel engine equipped with a "pump-line-nozzle" direct injection fuel system (Figure 11). The fuel injection pump was a fixeddisplacement type, mechanically-governed Bosch P7100 unit, and injection timing was held constant for all fuels tested. Engine specifications are listed in Table 4.

\section{Table 3. Fuel Properties for Baseline Diesel D2}

\begin{tabular}{|l|c|}
\hline Density @ 20 ${ }^{\circ} \mathrm{C}, \mathrm{kg} / \mathrm{litre}$ & 0.8473 \\
\hline Viscosity @ $40^{\circ} \mathrm{C}, \mathrm{cSt}$ & 3.97 \\
\hline Cetane Number & 49.1 \\
\hline Sulfur, ppm & 98 \\
\hline Nitrogen, ppm & 5 \\
\hline SFC Total Aromatics, Wt.\% & 16.32 \\
\hline SFC PNA, Wt.\% & 4.09 \\
\hline Distillation by D86, ${ }^{\circ} \mathrm{C}$ & \\
Initial Boiling Point & 173 \\
$10 \%$ & 237 \\
$50 \%$ & 299 \\
$90 \%$ & 336 \\
End Point & 358 \\
\hline
\end{tabular}

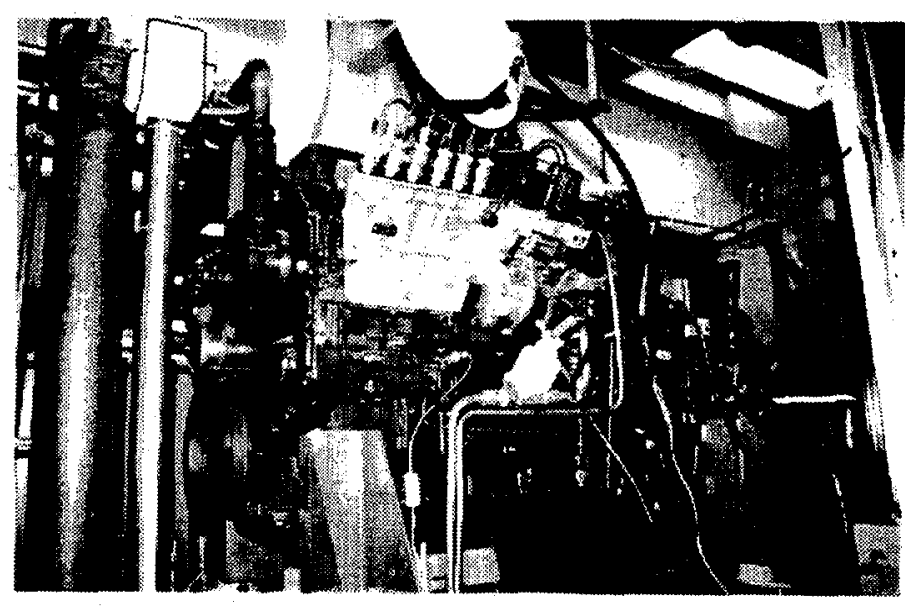

Figure 11. Cummins B5.9 Diesel Engine Installed in the Test Cell

Table 4. Test Engine Specifications

\begin{tabular}{|l|c|}
\hline Model year & 1993 Cummins B Series \\
\hline Displacement & 5.88 litres (359 in $\left.{ }^{3}\right)$ \\
\hline No. of cylinders & 6 inline \\
\hline Bore & $102 \mathrm{~mm}(4.02 \mathrm{in})$ \\
\hline Stroke & $120 \mathrm{~mm}(4.72 \mathrm{in})$ \\
\hline Compression ratio & $17.6: 1$ \\
\hline Horsepower rating & $131 \mathrm{~kW}(175 \mathrm{hp}) @ 2500 \mathrm{rpm}$ \\
\hline Torque rating & $570 \mathrm{~N}-\mathrm{m}(420 \mathrm{ft}-\mathrm{lb}) @ 1600 \mathrm{rpm}$ \\
\hline Aspiration & turbocharged and aftercooled \\
\hline Injection timing & $11.5^{\circ} \mathrm{BTDC}$ Fixed \\
\hline
\end{tabular}

Exhaust emissions and fuel consumption measurements were taken at nine steady state engine operating modes (Appendix). The modal points were chosen to allow direct comparisons of brake specific emissions over a variety of engine operating speeds and loads. No attempts were made to adjust the engine operation for use with the different fuels. The engine was unable to produce full power when fueled with methylal blends having lower energy densities, because the injection volume limit of the fixed-displacement fuel pump was reached. Therefore, the rated torque and rated power operating conditions were excluded from the modal test plan. The engine was able to produce $75 \%$ of the full power for all test fuels.

Gaseous emissions were measured using Horiba gas analyzers, and particulate matter was determined by collecting filter paper samples from a mini-dilution tunnel and weighing them with a microbalance. Fuel consumption was measured with a variable area 
Table 5: Averaged Exhaust Emissions from 9-Mode Steady State Engine Tests

\begin{tabular}{|l|c|c|c|c|c|c|c|}
\hline Fuel & $\begin{array}{c}\text { THC, } \\
\text { g/bhp-hr }\end{array}$ & $\begin{array}{c}\text { CO, } \\
\text { g/bhp-hr }\end{array}$ & $\begin{array}{c}\text { CO2, } \\
\text { g/bhp-hr }\end{array}$ & $\begin{array}{c}\text { NOx, } \\
\text { g/bhp-hr }\end{array}$ & $\begin{array}{c}\text { PM, } \\
\text { g/bhp-hr }\end{array}$ & $\begin{array}{c}\text { NOx } \\
\text { Normalized } \\
\text { to Fuel D2 }\end{array}$ & $\begin{array}{c}\text { PM } \\
\text { Normalized } \\
\text { to Fuel D2 }\end{array}$ \\
\hline D2 & 0.11 & 0.78 & 472.81 & 4.00 & 0.044 & 1.000 & 1.000 \\
DMM05\% & 0.15 & 0.71 & 465.92 & 3.71 & 0.042 & 0.927 & 0.946 \\
DMM10\% & 0.15 & 0.79 & 473.97 & 3.74 & 0.038 & 0.934 & 0.862 \\
DMM20\% & 0.15 & 0.93 & 471.79 & 3.80 & 0.032 & 0.951 & 0.728 \\
DMM30\%* & 0.19 & 1.24 & 493.18 & 3.52 & 0.033 & 0.899 & 0.653 \\
\hline
\end{tabular}

*For DMM $30 \%$, only 8 modes used for modal averaging and normalizing

flowmeter (rotameter) which was individually calibrated for diesel and each methyla! blended fuel.

Emissions from each fuel are summarized in Figure 12 and Table 5. These emissions results were calculated using equally-weighted modal averaging, and normalized with respect to the baseline diesel fuel emissions result. A $20 \%$ methylal blend was very effective at reducing particulate matter (PM) emissions, by $27 \%$ on average relative to the baseline diesel fuel. A $30 \%$ methylal blend reduced PM by $35 \%$ on average, although an anomaly existed in the mode 6 test so this result was averaged and normalized using 8 mode data.

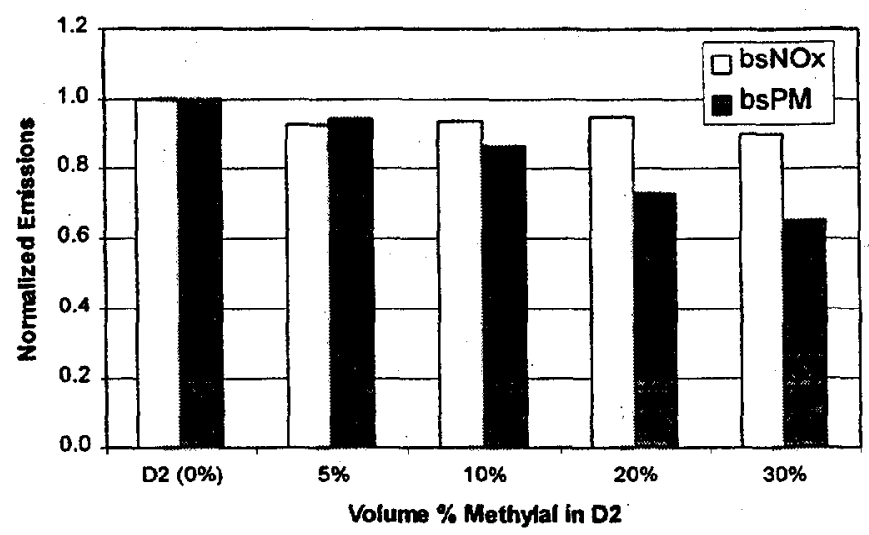

Figure 12. NOx and PM Emissions Averaged From 9 Mode Steady State Engine Tests

Reductions in oxides of nitrogen (NOX) emissions were apparent with increasing methylal blend level (Figure 12). However, these NOx reductions were accompanied by decreasing fuel conversion efficiencies as methylal concentration increased (Appendix). This NOxefficiency tradeoff was expected since the start of injection remained fixed for all test fuels. For the lower energy density fuels, a larger volume of fuel was injected over a longer duration to produce the same power as the baseline fuel, and this effectively retarded the heat release. With increasing methylal concentration, more fuel energy was being expended to produce the same brake power. Based on these test results and other findings [29], the NOx-efficiency tradeoff for the methylal-diesel blended fuels is similar to that of conventional diesel fuels.

Individual modal results for the $20 \%$ methylal- $80 \%$ diesel blend are shown in Figure 13. Brake specific NOx emissions were continuously reduced as speed increased and engine load decreased. PM emissions varied widely at different modes of engine operation. PM emissions ranged from a $76 \%$ reduction at mode 3 to a $37 \%$ increase at mode 1 , relative to the baseline diesel fuel. It was observed that the five highest power modes $(3,5,6,8,9)$ showed significant reductions in PM emissions while the four lowest power modes $(1,2,4,7)$ showed no change or significant increases in PM emissions. It was further observed that filter paper samples for the methylal blends were consistently visibly lighter than those from the baseline diesel fuel, even in cases which they weighed more. This suggests that the contribution of adsorbed volatile compounds, which is more significant at lower engine temperatures, may be the cause of the higher PM measurements at the lower power modes. The results also suggest that optimization of injection timing, rate, pressure and spray patterns may also result in further PM reductions.

Attempts were made to operate the engine on neat $(100 \%)$ methylal. The engine was unable to start on neat methylal and could only be operated at the low power modes. Even at low power conditions, engine operation was somewhat unstable, and extremely high hydrocarbon and carbon monoxide measurements indicated the occurrence of incomplete combustion and/or misfires. 
$20 \%$ DMM Blend in D2

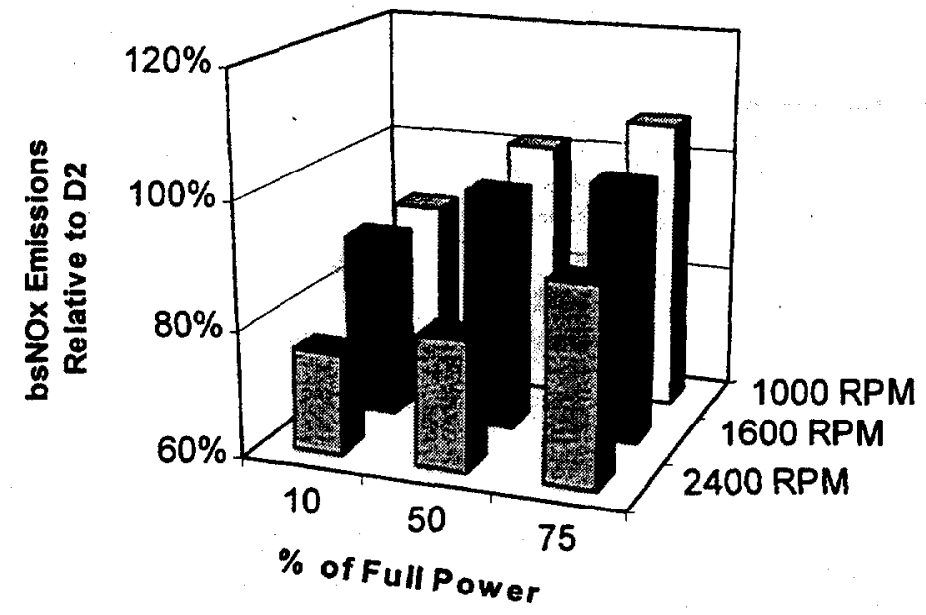

20\% DMM Blend in D2

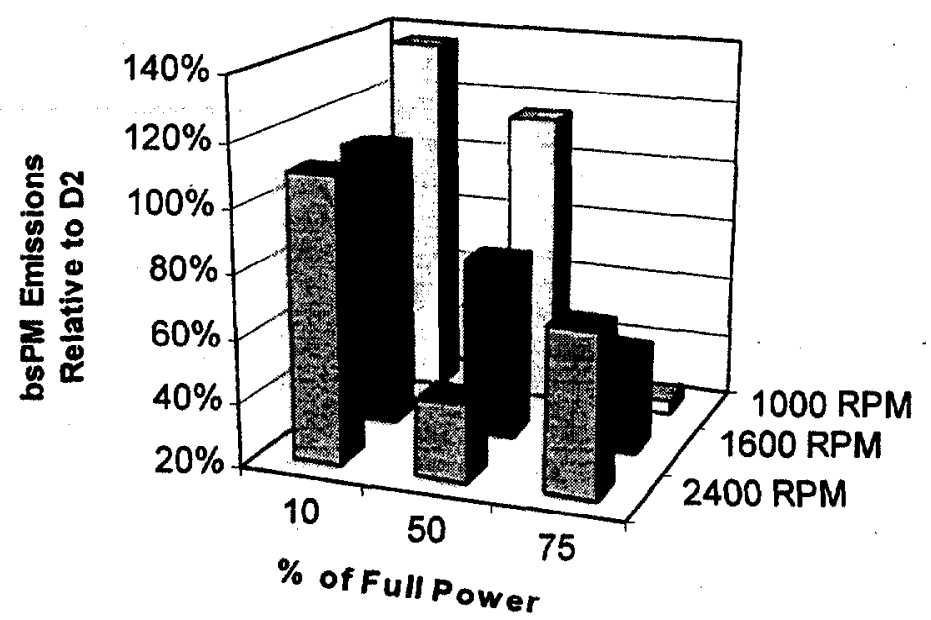

Figure 13. 9 Mode Emissions Test Results for the $20 \%$ Methylal- $80 \%$ Diesel Fuel Blend

\section{CONCLUSIONS}

- Methylal-diesel blended fuels are more volatile than conventional diesel fuels, and could not be safely substituted for diesel fuel in unmodified vehicles. Fuel distribution issues and vehicle design issues have been highlighted in this paper.

- Methylal is not a cetane improver, but could still be an effective blendstock because it does not reduce the cetane number of diesel fuel until blend levels exceed about $30 \%$ by volume.

- Substantial particulate matter (PM) emission reductions have been demonstrated for 10 to $30 \%$ methylal blends in diesel fuel, using a variety of unmodified diesel engines.

- Blending $30 \%$ methylal in diesel fuel reduced PM emissions by $35 \%$ based on modal averaged test results from the Cummins B5.9 diesel engine.

- The NOx-efficiency tradeoff for the methylal-diesel blended fuels is similar to that of conventional diesel fuels.

- The addition of impurities $(7.5 \%$ methanol and $0.5 \%$ water) reduced the cetane number and lubricity of methylal, and the methanol came out of solution when $20 \%$ impure methylal was blended with diesel fuel.

- Further research is recommended to optimize engine systems and controls for use with oxygenated fuels, to determine if greater emissions reductions can be realized.

\section{ACKNOWLEDGEMENTS}

The authors wish to acknowledge James Eberhardt, Stephen Goguen, John Garbak, and Richard Wares of the U.S. Department of Energy for providing technical direction and funding for this project. The authors also acknowledge the technical contributions and support provided by Paul Lacey and Ed Owens, Southwest Research Institute; Arun Basu and David Redeker, BP Amoco; Gary Hunter, Tom Gallant, Louis Broering and James Patten, Cummins Engine Company; and Manuch Nikanjam, Chevron.

\section{REFERENCES}

1. U.S. Energy Information Administration, International Energy Outlook 1998.

2. Atlantic Richfield Co., reprinted in Gas-to-Liquids News, Hart Publications, Vol. I, No. 1, Oct. 1998.

3. Lucas-Clements, C., "Where is the Stranded Gas? Petroconsultants-MAl", Monetizing Stranded Gas Reserves '98 (Zeus Development Corporation), 1998.

4. Gradassi, M., "Gas-to-Liquids Manufacturing Economics", Monetizing Stranded Gas Reserves '98 (Zeus Development Corporation), 1998.

5. Thijssen, J., "Natural Gas Monetizing Options", Monetizing Stranded Gas Reserves '98 (Zeus Development Corporation), 1998.

6. Moses, C., "Engine Experiments with Alcohol/Diesel Fuel Blends", Third International Symposium on Alcohol Fuels Technology, 1979.

7. Moses, C., Ryan, T. and Likos, W. "Experiments with Alcohol/Diesel Fuel Blends in Compression-Ignition Engines", Fourth International Symposium on Alcohol Fuels Technology, 1980.

8. Wood, C., "Alternative Fuels in Diesel EnginesA Review", SAE Paper 810248, 1981. 
9. Fleisch, T., McCarthy, C., Basu, A., Udovich, C., Charbonneau, P., Slodowske, W., Mikkelsen, S. and McCandless, J., "A New Clean Diesel Technology: Demonstration of ULEV Emissions on a Navistar Diesel Engine Fueled with Dimethyl Ether", SAE Paper 950061, 1995.

10. Kajitani, S., Chen, Z., Konno, M. and Rhee, K., "Engine Performance and Exhaust

Characteristics of Direct-Injection Diesel Engine Operated with DME", SAE Paper 972973, 1997.

11. McCandless, J. and Li, S., "Development of a Novel Fuel Injection System (NFIS) for Dimethyl Ether- and Other Clean Alternative Fuels", SAE Paper 970220, 1997.

12. Ofner, H, Gill, D. and Kammerdiener, T., "A Fuel Injection System Concept for Dimethyl Ether", IMechE Paper C517/022/96, 1996.

13. Spreen, K., Ullman, T. and Mason, R., "Effects of Cetane Number, Aromatics, and Oxygenates on Emissions From a 1994 Heavy-Duty Engine With Exhaust Catalyst", SAE Paper 950250, 1995.

14. Peckham, J., "Cetaner Blend Aims to Cut Emissions, Avoid Cost Penalty", Hart's Fuel Technology and Management, July/August, 1998.

15. Schuler, R., Hardin, B., Niemeier, R., Booth, G., Hazelden, K., Piccirillo, V., Smith, K., "Results of Testing Fifteen Glycol Ethers in a Short-term in vivo Reproductive Toxicity Assay", Environmental Health Perspectives, Vol. 57, 1984.

16. Plasterer, M., Bradshaw, W., Booth, G., Carter, M., Schuler, R., Hardin, B., "Developmental Toxicity of Nine Selected Compounds Following Prenatal Exposure in the Mouse: naphthalene, p-nitrophenol, sodium selenite, dimethyl phthalate, ethylenethiourea, and four glycol ether derivatives", J. of Toxicology and Environmental Health, Vol. 15, 1985.

17. Hardin, B., Eisenmann, C., "Relative Potency of Four Ethylene Glycol Ethers for Induction of Paw Malformations in the CD-1Mouse", Teratology, Vol. 35, 1987.

18. Takahashi, F. and Glassman, I., "Sooting Correlations for Premixed Flames", Combustion Science and Technology, Vol. 37, 1984.

19. Harris, M., King, G. and Laurendeau, N., "Influence of Temperature and Hydroxyl Concentration on Incipient Soot Formation in Premixed Flames", Combustion and Flame, Vol. 64, 1986.

20. Beaujean, M., "DMM as a Diesel Fuel Component", Monetizing Stranded Gas Reserves '98 (Zeus Development Corporation), 1998.

21. Lambiotte \& ClE, "Methylal Toxicological Profile", Brussels, Belgium, 1997.

22. Lambiotte \& CIE, "Methylal Ecotoxicological Profile", Brussels, Belgium, 1997.

23. Wallington, T., Hurley, M., Ball, J., Straccia, A., Platz, J., Christensen, L., Sehested, J., Nielsen,
O., "Atmospheric Chemistry of

Dimethoxymethane: Kinetics and Mechanism of Its Reaction with $\mathrm{OH}$ Radicals and Fate of the Alkoxy Radicals", J. Physical Chemistry, Vol. 101, 1997.

24. Naegeli, D., "Fuel Additives for Smoke Reduction in Diesel Engines", Southwest Research Institute Report 03-130, 1992.

25. Dodge, L. and Naegeli, D., "Combustion Characterization of Methylal in Reciprocating Engines", National Renewable Energy Laboratory Subcontractor Report NREL/TP-4256345, 1994.

26. Naegeli, D., "Practical Ignition Limits for Low Molecular Weight Alcohols", Fuel, Vol. 68, 1989.

27. Edgar, B., Dibble, R. and Naegeli, D., "Autoignition of Dimethyl Ether and Dimethoxymethane Sprays at High Pressures", SAE Paper 971677, 1997.

28. Edgar, B., "Dimethyl Ether and Other Oxygenated Fuels for Low Emission Diesel Engine Combustion", University of California at Berkeley, PhD Dissertation, 1997.

29. Sirman, M., Owens, E., Whitney, K., "Emissions Comparison of Alternative Fuels in an Advanced Automotive Diesel Engine", Southwest Research Institute Report for DOE and US Army TARDEC, Interim Report TFLRF No. 338, 1998.

30. Maricq, M., Chase, R., Podsiadlik, D., Siegl, W., Kaiser, E., "The Effect of Dimethoxymethane Additive on Diesel Vehicle Particulate Emissions", SAE Paper 982572, 1998.

31. Lacey, P., "Development of a Pressurized Wear Test Chamber", Letter Report to the National Renewable Energy Laboratory, June 17, 1998. 


\begin{tabular}{|c|c|c|c|c|c|c|c|c|c|}
\hline Mode & $\begin{array}{l}\text { Engine } \\
\text { Speed, } \\
\text { RPM }\end{array}$ & $\begin{array}{c}\text { Brake } \\
\text { Power, } \\
\text { bhp }\end{array}$ & Fuel & $\begin{array}{r}\text { THC, } \\
\text { g/bhp-hr }\end{array}$ & $\begin{array}{r}\mathrm{CO}, \\
\text { g/bhp-hr } \\
\end{array}$ & $\begin{array}{r}\text { NOx, } \\
\text { g/bhp-hr }\end{array}$ & $\begin{array}{r}\text { PM, } \\
\text { g/bhp-hr }\end{array}$ & $\begin{array}{r}\text { CO2, } \\
\text { g/bhp-hr } \\
\end{array}$ & $\begin{array}{r}\text { Fuel } \\
\text { Conversion } \\
\text { Efficiency* }\end{array}$ \\
\hline \multirow[t]{5}{*}{1} & 1000 & 6.5 & D2 & 0.489 & 4.261 & 9.883 & 0.117 & 708.23 & $19 \%$ \\
\hline & & & DMM05\% & 0.696 & 4.373 & 9.296 & 0.156 & 687.53 & $15 \%$ \\
\hline & & & DMM10\% & 0.696 & 4.951 & 8.256 & 0.165 & 675.09 & $18 \%$ \\
\hline & & & DMM20\% & 0.704 & 5.096 & 8.852 & 0.160 & 707.87 & $15 \%$ \\
\hline & & & DMM $30 \%$ & 0.598 & 4.833 & 9.241 & 0.148 & 719.14 & $18 \%$ \\
\hline \multirow[t]{5}{*}{2} & 1000 & 32.4 & $\mathrm{D} 2$ & 0.086 & 0.413 & 5.084 & 0.025 & 406.18 & $37 \%$ \\
\hline & & & DMM05\% & 0.112 & 0.359 & 5.684 & 0.032 & 419.45 & $28 \%$ \\
\hline & & & DMM10\% & 0.136 & 0.435 & 4.424 & 0.031 & 395.34 & $32 \%$ \\
\hline & & & DMM20\% & 0.111 & 0.437 & 5.161 & 0.029 & 402.14 & $30 \%$ \\
\hline & & & DMM30\% & 0.097 & 0.434 & 4.854 & 0.023 & 406.82 & $36 \%$ \\
\hline \multirow[t]{5}{*}{3} & 1000 & 48.6 & $\mathrm{D} 2$ & 0.059 & 1.320 & 4.948 & 0.072 & 412.56 & $35 \%$ \\
\hline & & & DMM05\% & 0.080 & 0.552 & 5.044 & 0.032 & 397.96 & $30 \%$ \\
\hline & & & DMM10\% & 0.076 & 0.596 & 5.106 & 0.032 & 408.18 & $36 \%$ \\
\hline & & & DMM20\% & 0.080 & 0.349 & 5.272 & 0.018 & 391.48 & $29 \%$ \\
\hline & & & DMM30\% & 0.078 & 0.365 & 4.853 & 0.018 & 395.30 & $32 \%$ \\
\hline \multirow[t]{5}{*}{4} & 1600 & 12.8 & D2 & 0.487 & 4.370 & 5.494 & 0.123 & 690.41 & $22 \%$ \\
\hline & & & DMM05\% & 0.580 & 4.116 & 5.403 & 0.161 & 681.64 & $19 \%$ \\
\hline & & & DMM10\% & 0.623 & 4.830 & 4.583 & 0.157 & 665.04 & $17 \%$ \\
\hline & & & DMM20\% & 0.634 & 5.583 & 4.882 & 0.135 & 690.57 & $13 \%$ \\
\hline & & & DMM30\% & 0.697 & 5.941 & 4.786 & 0.109 & 695.96 & $19 \%$ \\
\hline \multirow[t]{5}{*}{5} & 1600 & 64.0 & D2 & 0.059 & 0.222 & 4.361 & 0.019 & 412.01 & $38 \%$ \\
\hline & & & DMM05\% & 0.083 & 0.212 & 3.983 & 0.021 & 400.09 & $32 \%$ \\
\hline & & & DMM10\% & 0.071 & 0.241 & 4.262 & 0.019 & 412.13 & $35 \%$ \\
\hline & & & DMM20\% & 0.088 & 0.233 & 4.274 & 0.014 & 412.23 & $33 \%$ \\
\hline & & & DMM30\% & 0.076 & 0.346 & 3.872 & 0.014 & 417.08 & $26 \%$ \\
\hline \multirow[t]{5}{*}{6} & 1600 & 96.0 & D2 & 0.054 & 0.102 & 4.317 & 0.019 & 409.25 & $40 \%$ \\
\hline & & & DMM05\% & 0.084 & 0.112 & 3.908 & 0.018 & 402.24 & $34 \%$ \\
\hline & & & DMM10\% & 0.050 & 0.100 & 4.271 & 0.013 & 411.89 & $31 \%$ \\
\hline & & & DMM20\% & 0.040 & 0.091 & 4.359 & 0.010 & 409.37 & $30 \%$ \\
\hline & & & DMM30\% & NA & NA & NA & NA & NA & NA \\
\hline \multirow[t]{5}{*}{7} & 2400 & 16.5 & $\mathrm{D} 2$ & 0.920 & 7.323 & 4.422 & 0.282 & 958.35 & $17 \%$ \\
\hline & & & DMM05\% & 1.124 & 7.078 & 4.327 & 0.279 & 952.10 & $14 \%$ \\
\hline & & & DMM10\% & 1.394 & 7.900 & 3.833 & 0.276 & 936.22 & $14 \%$ \\
\hline & & & DMM20\% & 1.346 & 9.747 & 3.361 & 0.311 & 947.77 & $9 \%$ \\
\hline & & & DMM30\% & 1.742 & 12.047 & 3.314 & 0.257 & 966.11 & $9 \%$ \\
\hline \multirow[t]{5}{*}{8} & 2400 & 82.3 & D2 & 0.076 & 0.555 & 2.974 & 0.048 & 484.16 & $28 \%$ \\
\hline & & & DMM05\% & 0.134 & 0.626 & 2.522 & 0.042 & 485.80 & $28 \%$ \\
\hline & & & DMM10\% & 0.115 & 0.738 & 2.623 & 0.038 & 518.78 & $25 \%$ \\
\hline & & & DMM20\% & 0.141 & 1.230 & 2.399 & 0.021 & 504.54 & $23 \%$ \\
\hline & & & DMM30\% & 0.142 & 1.097 & 2.396 & 0.023 & 517.09 & $21 \%$ \\
\hline \multirow[t]{5}{*}{9} & 2400 & 123.4 & D2 & 0.060 & 0.189 & 3.067 & 0.024 & 487.54 & $33 \%$ \\
\hline & & & DMM05\% & 0.098 & 0.228 & 2.599 & 0.027 & 476.27 & $30 \%$ \\
\hline & & & DMM10\% & 0.087 & 0.245 & 2.731 & 0.020 & 478.80 & $31 \%$ \\
\hline & & & DMM20\% & 0.054 & 0.214 & 2.802 & 0.017 & 480.54 & $27 \%$ \\
\hline & & & DMM30\% & 0.053 & 0.236 & 2.819 & 0.014 & 481.75 & $28 \%$ \\
\hline
\end{tabular}

*Fuel Conversion Efficiency $=$ brake power $/$ (mass flow rate of fuel * heating value of fuel) 